\title{
Genetic Variations in Renin-Angiotensin-Aldosterone System (RAAS) Genes Could Contribute to High Altitude Pulmonary Edema: Review
}

\section{Swati Srivastava*}

School of Biotechnology, Gautam Buddh University, Greater Noida, Uttar Pradesh, India

\begin{abstract}
Background: At High Altitude (HA) (elevation $>2500 \mathrm{~m}$ ), inevitable hypobaric hypoxia leads to development of symptoms associated with low oxygen pressure in many non acclimatized sojourners which includes severe forms of altitude mountain sickness (AMS) such as high altitude pulmonary edema (HAPE) and high altitude cerebral edema (HACE). These syndromes are reportedly less common in high altitude native population than in lowlanders which can be attributed to genetic adaptations that have taken place over generations.

Methods: Numerous genetic studies have been associated with hypoxic adaptation and susceptibility to high altitude conditions. An increased pulmonary arterial pressure (PAP) and fluid loss has been observed in all forms of AMS with varied intensity. Since renin-angiotensin-aldosterone system (RAAS) has a critical function of maintaining homeostasis in closed circulatory system, the polymorphisms occurring in the genes of RAAS pathway could likely be contributing towards acclimatization/mal-adaptation to high altitude maladies. In view of above, this review has been compiled to associate the genetic variations in RAAS with adaptation/acclimatization to high altitude conditions.
\end{abstract}

Results: Studies conducted so far relate allele frequencies of polymorphic loci in genes encoding components of RAAS pathway such as angiotensinogen (AGT), angiotensin converting enzyme (ACE), angiotensin receptors (AT1) and aldosterone synthase (CYP11B2) and associate them with hypertension, regulation of blood pressure and maintenance of osmotic balance in the body.

Conclusions: In this review, various studies have been put together comprehensively indicating the involvement of genetic variants of RAAS genes in resistance or sensitivity of an individual towards development of HAPE.

Keywords: AMS; High Altitude; HAPE; Polymorphism; RAAS

\section{Background}

Mountains cover over one-fifth of the earth's surface and are popular tourist destinations. Large numbers of people travel to high altitudes for various reasons such as trekking, mining, pilgrimage, tourism and also military personnel are deployed at high altitude for guarding the borders of the country. Low atmospheric pressure of high altitude results in 'hypobaric hypoxic' condition which further elicits interest in the adaptation of these sojourners and the high altitude inhabiting populations living in these adverse altitudinal environments for centuries. Exposure to the oxygen depleted environment triggers the onset of a range of physiological and biochemical reactions which primarily gears the individual towards the enhancement of efficacy of body's respiratory [1], cardiovascular and oxygen utilization system [2] through the process of acclimatization. During altitude acclimatization, the various physiological adaptations can have immediate effects such as hyperventilation, fluid loss due to a decreased thirst drive, increased heart rate and slightly lowered stroke volume. "Altitude Sickness" is commonly used term for syndromes encountered at an altitude above 2,500m, comprising of acute mountain sickness (AMS), high altitude cerebral edema (HACE) and high altitude pulmonary edema (HAPE). Besides these, other high altitude diseases include chronic mountain sickness, sub-acute mountain sickness and the less severe retinal hemorrhage. Rate of ascent, altitude reached, pre-acclimatization and individual susceptibility are the major determinants of susceptibility towards high altitude maladies in healthy individuals. Studies on different populations have suggested variability in individual susceptibility to altitude sickness depending on genetic makeup [3]. Genetic variations provides a possible mechanism to explain inter-individual variation in performance in response to hypoxia/susceptibility to HAPE. Significant association between genetic polymorphic variants of renin- angiotensinaldosterone system (RAAS) and the occurrence/sensitivity of HAPE was identified. However, the definite roles of some SNPs in RAAS genes still require better clarification. In a recent study by Mishira and co- workers, a genome wide scan on 288 subjects including HAPE patients, resistant controls and high altitude natives, they found 138 SNPs that include genes involved in RAAS pathway; angiotensinogen, angiotensin receptor 1 and angiotensin converting enzyme 2 are associated with the changes in the changes in the apelin signaling system, which regulates vascular and oxygen homeostasis [4].

RAAS is viewed as a major circulating system wherein kidneyderived enzyme renin cleaves liver derived angiotensinogen to form angiotensin I (Ang I) in blood. Subsequently, Ang I is converted into Angiotensin II (Ang II), the main effector peptide of the RAAS, by angiotensin I-converting enzyme (ACE) located in the lumen of endothelium. Ang II exerts its effects via stimulation of Ang II receptors, such as $\mathrm{AT}_{1}$ and $\mathrm{AT}_{2}$. When there is a decrease in blood volume, reduced salt transport to the distal tubule or increased renal sympathetic tone, juxtaglomerular cells in the kidneys secrete renin directly into circulation. RAAS is known as a major endocrine/ paracrine system involved in maintaining the arterial blood pressure and is considered as a critical system controlling homeostatic function in animals with closed circulatory system. The RAAS plays a central role in managing renal and cardiovascular functions by maintaining

${ }^{*}$ Corresponding author: Swati Srivastava, Assistant Professor (Guest faculty), School of Biotechnology, Gautam Buddh University, F-002, T9, Lotus Panache, Sector -110, Noida (201301), Uttar Pradesh, India, E-mail: sri_swati@rediffmail.com

Received September 22, 2014; Accepted November 22, 2015; Published November 27,2015

Citation: Srivastava S (2015) Genetic Variations in Renin-Angiotensin-Aldosterone System (RAAS) Genes Could Contribute to High Altitude Pulmonary Edema: Review. J Pulm Respir Med 5: 296. doi:10.4172/2161-105X.1000296

Copyright: @ 2015 Srivastava S. This is an open-access article distributed unde the terms of the Creative Commons Attribution License, which permits unrestricted use, distribution, and reproduction in any medium, provided the original author and source are credited. 
the physiological homeostasis of blood pressure and electrolyte balance (Figure 1). Angiotensin II (Ang II) is regarded as the major bioactive effector of RAAS being involved in a variety of biological actions including the homeostasis of many organ systems. It is considered as best characterized circulating vasomodulator [5]. This potent vasoconstrictor is synthesized from angiotensinogen (AGT) through a two step process in which AGT is first converted to a decapeptide Ang I by renin and then to octapeptide Ang II by action of ACE. Ang II is a very potent chemical that causes the muscles surrounding the blood vessels to contract, which thereby narrows the blood vessels. This narrowing increases the pressure within the vessels and can cause high blood pressure. A series of signaling reactions is triggered when Ang II binds to its receptors that eventually results in the $\mathrm{Ca}^{++}$-mediated contraction of vascular smooth muscles. In addition to this, Ang II is also involved in control of water and salt retention both at kidney level and also indirectly through the release of aldosterone. It also stimulates thirst and the release of vasopressin [6]. Thus this gene regulates blood pressure both at vessel level through the process of vasoconstriction and also at blood level by influencing the plasma volume. However, Ang II is nowadays considered more than just a vasoconstrictor and has trophic effects independent of its haemodynamic actions. Role of Ang II in cell differentiation and modulation of growth and hypertrophy has also been identified [7]. It also activates the angiogenic cytokines and related molecules and promotes macrophage recruitment and infiltration to a certain extent by increasing expression of the chemokine monocyte chemoattractant protein-1 (MCP-1) [8].

Ang II, which is regarded as the major product of the RAS, is believed to be involved in the development of cardiovascular (CV) pathologies including hypertension, heart failure, and cardiac and vascular fibrosis [9-11]. It also acts as a pro-fibrotic and pro-thrombotic agent with direct effects on the kidney including activation of an important transcription factor nuclear factor $\kappa$ beta (NFkB). Ang II upregulates NF- $\kappa B$ and activates endothelial and endocardial NADPH oxidase and related inflammatory genes $[12,13]$.

Abnormal activation of RAAS pathway has been linked with the pathogenesis of hypertension, associated vascular disorders [14], renal

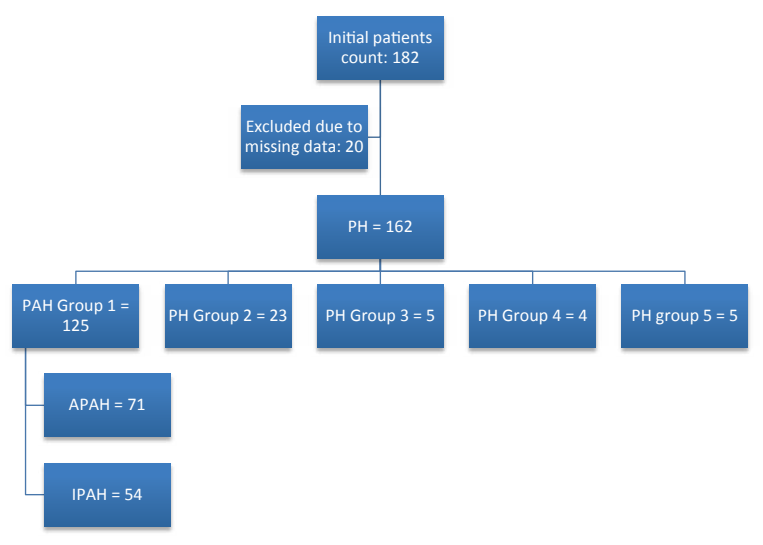

Figure 1: Schematic diagram showing effect of high altitude (HA) exposure and its immediate on individuals, which might cause AMS, HAPE or HACE in susceptible individuals. As a result of HA exposure, RAAS system activation is triggered which helps in maintaining haemostasis; blood pressure and electrolyte balance. diseases and myocardial infarction. Therefore, since RAAS pathway regulates many key factors that are disturbed during high altitude exposure, this review will discuss our current understanding of role of RAAS polymorphisms particularly in relation to development of high altitude maladies.

\section{RAAS pathway: Functional significance and vital distribution}

The hypothalamus contains ion channels that can sense the sodium concentration and extracellular fluid osmolarity. Glomerular filtration rate, the sympathetic nervous system, and the renin-angiotensinaldosterone system (RAAS) are the major volume effectors. Osmolarity effectors include thirst stimulation, release of the antidiuretic hormone vasopressin and the placement of aquaporin water channels in the renal collecting duct so that urine is concentrated. The RAAS is the principal volume-regulatory effector in mammals. It is a major regulator of blood pressure within the human body. Therefore, the RAAS has gained importance for study of hypertension and other cardiovascular diseases [14].

The angiotensinogen is the key effector molecule of RAAS, a protein which is produced principally in liver. Angiotensinogen is cleaved by a aspartyl protease, renin (REN), produced by the juxtaglomerular apparatus in the kidney into a 10 amino-acid peptide, angiotensin (Ang I) $[15,16]$. The Ang I is inturn cleaved by angiotensin converting enzyme (ACE) into highly active 8 amino-acid peptide, angiotensin II (Ang II). ACE is a matrix metalloproteinase that is highly concentrated on pulmonary endothelial cells particularly. Ang II acts on the adrenal cortex to release aldosterone (ALD) which in turn acts on the kidney, primarily on collecting duct cells to effect reabsorption of sodium (and chloride). Ang II has vital role as it also has its own independent sodium reabsorptive effects in the kidney, acts in brain to stimulate thirst and salt appetite, as well as increases sympathetic tone and acts directly on the vessel wall (primarily arterioles) to affect vasoconstriction and to increase blood pressure [17].

In addition to the systemic (circulating) RAAS, there are evidences indicating that many tissues, including the vasculature, heart, kidney and brain are capable of producing Ang II, which may thereby mediate autocrine, paracrine and intracrine effects $[18,19]$. Various studies have also shown that the components required for synthesis of Ang II, such as angiotensinogen, renin and ACE are present in such tissues $[20,21]$. Ang II us also produced via non-ACE and non-renin enzymes including cathepsin G, chymostatin-sensitive Ang II generating enzyme ('CAGE'), tissue plasminogen activator and tonin [22,23]. Moreover, other enzymes such as chymase, exhibit ACE-like activity. It is a protein mainly found in mast cells, which mostly displays such an activity in the heart [24].

Various genetic polymorphisms occur in the above mentioned genes of RAAS pathway. Some of the most common variations amongst these have been studied in detail across numerous studies to establish their relationship with different diseases. This review focuses on those single nucleotide polymorphisms (SNPs) in particular which disrupts body's homeostasis and thus could be contributing towards HAPE susceptibility.

\section{Common genetic polymorphisms of RAAS and their significance}

Renin (REN): REN catalyses the cleavage of angiotensinogen to the decapeptide angiotensin [25] and forms the rate-limiting step in Ang II production. A negative feedback loop inhibits renin release that includes Ang II levels, inactivated baroreflex sensors, and sympathetic inhibition. The renin gene has an intronic polymorphism $A / G$ is-83, 
that can be differentiated by restriction endonuclease MboI and has been studied in relation to primary hypertension [26], with some contradictory reports that showed lack of correlation between Mbo I polymorphism with essential hypertension in Japanese polulation [27].

Angiotensinogen (AGT): AGT is $\alpha$-2-globulin that is produced constitutively and released into the circulation mainly by the liver. AGT gene is located on chromosome Iq42-43 having five exons and four introns [28] with more than 20 molecular variants [29]. Of these, three polymorphisms have been studied very extensively: two mutations in exon 2, one is substitution of $704 \mathrm{~T}>\mathrm{C}$ resulting in a methionine to threonine exchange at position 235 (M235T) and the second is threonine to methionine substitution at position 174 (T174M); and the third polymorphism is a guanine to adenine substitution $6 \mathrm{bp}$ upstream from the initiation site of transcription in the promoter region $(-6 \mathrm{G}>\mathrm{A})$ [29]. $-6 \mathrm{G}>\mathrm{A}$ variant is in close linkage disequilibrium with M235T. The 235T allele has been shown to correlate significantly with hypertension and heart disease [30]. A T to $\mathrm{C}$ transition at base 704 (T/C704) substitutes a threonine for a methionine at residue 235 has also been associated with heart disease [31] and hypertension [Atwood]. In one of our previous studies, we found $A G T$ T174M to be significantly associated with HAPE sensitivity [32].

Angiotensin-I converting enzyme (ACE): ACE is a membranebound enzyme located in vascular endothelial cells and converts Ang I to active Ang II. The human ACE gene has been cloned and localized at chromosome $17 \mathrm{q} 23$ [33] with 26 exons. More than 100 polymorphisms have been identified at the ACE locus. Most importantly, a $287 \mathrm{bp}$ insertion/deletion (I/D) polymorphism in intron 16 has been identified for use as a genetic marker. In 1990, Rigat and co-workers [34] first described the insertion (I)/ deletion (D) polymorphism of the ACE gene. This SNP acts as a major locus that accounts for approximately $50 \%$ of the total phenotypic variance of circulating and tissue levels of ACE, as shown by various studies. The $\mathrm{D}$ allele has been associated with hypertension and various organ disorders, with conflicting results [35,36]. Moreover, I allele has been associated with endurance and adaptation at high altitude $[37,38]$. ACE is associated with the regulation of blood pressure and maintenance of salt and water homeostasis in the body [39]. It is also shown to inactivate a vasodilator and natriuretic peptide bradykinin hence could be an important determinant of HAPE susceptibility as it progresses with pulmonary vasoconstriction. In order to validate potential risk of ACE $I / D$ polymorphism and its role in development of HAPE, a metaanalysis was conducted which involved large data set comprising of 305 HAPE cases and 662 controls involved in six different studies [40]. This analysis established a significant association between the ACE $D$ allele carriers having 1.55-fold increased risk for developing HAPE as compared to those with the II genotype [40]. Positive association of D allele with high altitude pulmonary edema has been recently demonstrated in Indian population [41].

ACE is also associated with pathogenesis and progression of diabetic nephropathy. Ahluwalia and co-workers [42] found that ACE $D$ allele in interaction with other RAS single nucleotide polymorphisms significantly increases the risk of nephropathy in type 2 diabetic patients of Asian Indian origin.

Angiotensin converting enzyme 2 (ACE2): ACE2 enzyme was discovered almost 50 years after the discovery of angiotensin-converting enzyme (ACE) by two independent groups $[43,44]$ as a homologue of ACE. At that point of time it was denoted as captopril-insensitive carboxypeptidase [43] and ACE2 [44], the later is now the accepted in the literature. The human ACE2 gene maps to the chromosomal location Xp22. Since mRNA coding for ACE2 was initially identified in cardiovascular tissues, kidney and testis it might be playing a role in local RAAS. ACE2 functions as a carboxypeptidase converting Ang I to the nano-peptide angiotensin 1-9 (Ang1-9) and Ang II to the angiotensin 1-7 (Ang1-7) by removing a single amino acid residue from the carboxy terminus of the substrate. This action is discrete and complementary to the dipeptidyl carboxypeptidase activity of ACE that generates Ang II from Ang I. Ang1-7 promotes vasodilatation thus counterbalancing the vasoconstrictive effect of Ang II. In view of the enzymatic properties of ACE and ACE2 along with the mediators Ang II and Ang(1-7), Santos and co-workers [45] envisioned a new conception on RAAS, wherein it was considered as a dual function system with a focus on ACE/ACE2 activity ratio. Thus, the ACE/ACE2 balance determined the vasoconstrictor or vasodilator actions of the dual function system.

Association of ACE2 polymorphisms have been studied in relation with various diseases with conflicting results. While no association was reported between polymorphisms in ACE2 gene and hypertension in the northern Chinese Han population [46] and Anglo- Celtic Australian population [47], G/A polymorphism (rs2285666) was shown to be associated with hypertension in female Chinese patients with metabolic syndrome [48]. Patel and co-workers examined ACE2 genetic variants separately in male and female Caucasian subjects with type 2 diabetes and it was seen that hypertension was more prevalent in Caucasian women with the rs $4240157 \mathrm{G}$ allele and a higher LV mass was reported with rs1978124 A allele while the men had reduced systolic function [49].

Angiotensin receptors: Specific heterogenous populations of Ang II receptors mediate actions of Ang II. Ang II is known to interact with at least two distinct types of receptors designated as $\mathrm{AT}_{1}$ and $\mathrm{AT}_{2}$ [50]. All known actions of Ang II, including vasoconstriction, release of aldosterone, stimulation of sympathetic transmission and cellular growth, are exclusively mediated by the $\mathrm{AT}_{1}$ receptors [51,52]. However, the functional role of $\mathrm{AT}_{2}$ receptor is not fully understood, studies have shown its possible role in mediating anti-proliferation, apoptosis, differentiation and possibly vasodilation [53,54]. The affinity of Ang II for the AT1 receptor is dramatically decreased in presence of the reducing agent dithiothreitol and GTP analogues [55]. The gene for AT1 receptor was first cloned from rat vascular smooth muscle cells [56] and bovine adrenal gland [57]. The AT1 receptor gene product consists of 350 amino acids and has a molecular mass of $41 \mathrm{kDa}$. There are two known isoforms of the $\mathrm{AT} 1$ receptor in rodents, termed $\mathrm{AT}_{1 \mathrm{~A}}$ and $\mathrm{AT}_{1 \mathrm{~B}}$ which share $94 \%$ similarity. $\mathrm{AT}_{1 \mathrm{~A}}$ receptors are found predominantly in kidney, lung, liver and vascular smooth muscle, whereas $\mathrm{AT}_{1 \mathrm{~B}}$ receptors are expressed mainly in the adrenal and anterior pituitary glands. The AT1 receptor belongs to the seven transmembrane class of G-protein-coupled receptor [58]. The transmembrane domain and the extracellular loop play an important role in Ang II binding [59]. The $\mathrm{AT}_{1} \mathrm{R}$ gene maps to the long arm of chromosome 3 containing five exons [60]. In the AGTR1 gene, an A/C transversion at base 1166 (A/ C1166) also has been associated with hypertension [61,62] as well as the risk of developing myocardial infarcts [63]. Induction of pulmonary vasoconstriction due to hypoxia using Ang II via AT1R, suggests important roles of Ang II and AT1R in increasing pulmonary vascular tone that may result in pulmonary oedema [63].

Angiotensin receptor blockers (ARBs): These are the agents that block the action of angiotensin II and as a result blood vessel are dilated and blood pressure is reduced. The lower blood pressure makes it easier for the heart to pump and can improve heart failure. However, there are two main classes of agents that blunt RAS activity; angiotensin- 
converting enzyme inhibitor (ACEIs) and angiotensin receptor blockers (ARBs). Angiotensin-convrting enzyme inhibitors and ARBs not only lower the blood pressure but may also possess unique cardioprotective properties. They also reduce rates of death, myocardial infarction, stroke, cardiac arrest and revascularization procedures [64,65]. These agents are generally well tolerated, especially ARBs, which have side effect profile similar to that of placebo. Because of their tolerability profile, ARBs and ARB combination therapy may be an option for patients susceptible to ACEI-related adverse events [66].

Aldosterone synthase (CYP11B2): Aldosterone is a hormone that increases the reabsorption of sodium and water and the release of potassium in the kidneys. This increases blood volume and therefore increases blood pressure. AngII and aldosterone have also been shown to have direct modulatory effects on membrane ion channels. AngII induces L-type calcium channel in neonatal rabit cardiomyocytes [67] and rat portal vein vascular myocytes [68]. Aldosterone downregulates $\mathrm{I}_{\text {to }}$ and increased L-type calcium current in rat ventricular cells [69]. The net effect of enhanced calcium and reduced potassium currents would be action potential duration prolongation and re-polarization dispersion, both of which promote arrhythmias. Positive association of C-344T polymorphism in CYP11B2 gene with HAPE sensitivity has been demonstrated in Indian population [70].

\section{Summary}

The well-documented effects of RAAS that influence vascular tone, cardiovascular remodeling, salt and water homeostasis and cardiovascular diseases make the RAAS a logical candidate for evaluating susceptibility to high altitude maladies. Several studies done over the years show that the different polymorphisms which result in expression changes for different genes of RAAS pathway such as that of AGT, ACE, angiotensin receptors and CYP11B2, could be considered as important determining factors for HAPE susceptibility. Thus, integrating more and more information representing diverse genetic and molecular characteristics of RAAS gene expression along with clinical data could help to build a detailed profile of HAPE. Thus this clinical disorder can be better understood and strategies to deal with it can be formulated.

\section{References}

1. Smith CA, Dempsey JA, Hornbein TF (2001) Control of breathing at high altitude. In: Hornbein TF, Schoene RB, editors. High altitude: an exploration of human adaptation. New York: Marcel Dekker 139-173.

2. Hohenhaus E, Paul A, McCullough RE, Kücherer H, Bärtsch P (1995) Ventilatory and pulmonary vascular response to hypoxia and susceptibility to high altitude pulmonary oedema. Eur Respir J 8: 1825-1833.

3. Patel S, Peacock A (2001) Who will cope at high altitude: is it in the genes? ISMM News 11: 5-8.

4. Mishra A, Kohli S, Dua S, Thinlas T, Mohammad G, et al. (2015) Genetic differences and aberrant methylation in the apelin system predict the risk of high-altitude pulmonary edema. Proc Natl Acad Sci U S A 112: 6134-6139.

5. Opie LH (1999) Angiotensin converting enzyme inhibitors ( $3^{\text {rd }}$ Edn), Cape Town: University of Cape Town Press.

6. Ondetti MA, Rubin B, Cushman DW (1977) Design of specific inhibitors of angiotensin-converting enzyme: new class of orally active antihypertensive agents. Science 196: 441-444.

7. Wolf G, Wenzel UO (2004) Angiotensin II and cell cycle regulation. Hypertension 43: 693-698.

8. Sadoshima J (2000) Cytokine actions of angiotensin II. Circ Res 86: 1187-1189.

9. Holtz J (1993) Pathophysiology of heart failure and the renin-angiotensinsystem. Basic Res Cardiol 88 Suppl 1: 183-201.

10. Weber KT (1997) Extracellular matrix remodeling in heart failure: a role for de novo angiotensin II generation. Circulation 96: 4065-4082.

11. Ruiz-Ortega M, Lorenzo O, Rupérez M, Esteban V, Suzuki Y, et al. (2001) Role of the renin-angiotensin system in vascular diseases: expanding the field. Hypertension 38: 1382-1387.

12. Oudot A, Vergely C, Ecarnot-Laubriet A, Rochette L (2003) Angiotensin II activates NADPH oxidase in isolated rat hearts subjected to ischaemiareperfusion. Eur J Pharmacol 462: 145-154.

13. Nakagami H, Takemoto M, Liao JK (2003) NADPH oxidase-derived superoxide anion mediates angiotensin II-induced cardiac hypertrophy. J Mol Cell Cardio 35: 851-859.

14. Cushman DW, Ondetti MA (1999) Design of angiotensin converting enzyme inhibitors. Nat Med 5: 1110-1113.

15. Ganten D, Hayduk K, Brecht HM, Boucher R, Genest J (1970) Evidence of renin release or production in splanchnic territory. Nature 226: 551-552.

16. Ganten D, Minnich JL, Granger P, Hayduk K, Brecht HM, et al. (1971) Angiotensin-forming enzyme in brain tissue. Science 173: 64-65.

17. Bader M, Ganten D (2008) Update on tissue renin-angiotensin systems. J Mol Med (Berl) 86: 615-621.

18. Campbell DJ (1987) Circulating and tissue angiotensin systems. J Clin Invest 79: $1-6$.

19. Johnston Cl (1992) Franz Volhard Lecture. Renin-angiotensin system: a dual tissue and hormonal system for cardiovascular control. J Hypertens Suppl 10: S13-26.

20. Vinson GP, Ho MM, Puddefoot JR (1995) The distribution of angiotensin II type 1 receptors, and the tissue renin-angiotensin systems. Mol Med Today 1: 35-39.

21. Phillips MI, Speakman EA, Kimura B (1993) Levels of angiotensin and molecular biology of the tissue renin angiotensin systems. Regul Pept 43: 1-20.

22. Urata H, Nishimura H, Ganten D (1995) Mechanisms of angiotensin II formation in humans. Eur Heart J 16 Suppl N: 79-85.

23. Urata H, Nishimura H, Ganten D, Arakawa K (1996) Angiotensin-converting enzyme-independent pathways of angiotensin II formation in human tissues and cardiovascular diseases. Blood Press Suppl 2: 22-28.

24. Urata H, Boehm KD, Philip A, Kinoshita A, Gabrovsek J, et al. (1993) Cellular localization and regional distribution of an angiotensin II-forming chymase in the heart. J Clin Invest 91: 1269-1281.

25. Malik FS, Lavie CJ, Mehra MR, Milani RV, Re RN (1997) Renin-angiotensin system: genes to bedside. Am Heart J 134: 514-526.

26. Frossard PM, Lestringant GG, Elshahat YI, John A, Obineche EN (1998) An Mbol two-allele polymorphism may implicate the human renin gene in primary hypertension. Hypertens Res 21: 221-225.

27. Fu Y, Katsuya T, Asai T, Fukuda M, Inamoto N, et al. (2001) Lack of correlation between Mbo I restriction fragment length polymorphism of renin gene and essential hypertension in Japanese. Hypertens Res 24: 295-298.

28. Jeunemaitre X, Inoue I, Williams C, Charru A, Tichet J, et al. (1997) Haplotypes of angiotensinogen in essential hypertension. Am J Hum Genet 60: 1448-1460.

29. Tang W, Devereux RB, Rao DC, Oberman A, Hopkins PN, et al. (2002) Associations between angiotensinogen gene variants and left ventricular mass and function in the HyperGEN study. Am Heart J 143: 854-860.

30. Katsuya T, Koike G, Yee TW, Sharpe N, Jackson R, et al. (1995) Association of angiotensinogen gene T235 variant with increased risk of coronary heart disease. Lancet 345: 1600-1603.

31. Atwood LD, Kammerer CM, Samollow PB, Hixson JE, Shade RE, et al. (1997) Linkage of essential hypertension to the angiotensinogen locus in Mexican Americans. Hypertension 30: 326-330.

32. Srivastava S, Bhagi S, Kumari B, Chandra K, Sarkar S, et al. (2012) Association of polymorphisms in angiotensin and aldosterone synthase genes of the reninangiotensin-aldosterone system with high-altitude pulmonary edema. J Renin Angiotensin Aldosterone Syst 13: 155-160

33. Mattei MG, Hubert C, Alhenc-Gelas F, Roekel N, Corvol P et al. (1989) Angiotensin I-converting enzyme gene is on chromosome 17. Cytogenet cell Genet. 51: 1041

34. Rigat B, Hubert C, Alhenc-Gelas F, Cambien F, Corvol P, et al. (1990) An insertion/deletion polymorphism in the angiotensin I-converting enzyme gene 
Citation: Srivastava S (2015) Genetic Variations in Renin-Angiotensin-Aldosterone System (RAAS) Genes Could Contribute to High Altitude Pulmonary Edema: Review. J Pulm Respir Med 5: 296. doi:10.4172/2161-105X.1000296

Page 5 of 5

accounting for half the variance of serum enzyme levels. J Clin Invest 86: 13431346.

35. Danser AH, Schalekamp MA, Bax WA, van den Brink AM, Saxena PR, et al. (1995) Angiotensin-converting enzyme in the human heart. Effect of the deletion/insertion polymorphism. Circulation 92: 1387-1388.

36. Zee RY, Ridker PM, Stampfer MJ, Hennekens CH, Lindpaintner K (1999) Prospective evaluation of the angiotensin-converting enzyme insertion/deletion polymorphism and the risk of stroke. Circulation 99: 340-343.

37. Gayagay G, Yu B, Hambly B, Boston T, Hahn A, et al. (1998) Elite endurance athletes and the ACE I allele--the role of genes in athletic performance. Hum Genet 103: 48-50.

38. Qadar Pasha MA, Khan AP, Kumar R, Grover SK, Ram RB, et al. (2001) Angiotensin converting enzyme insertion allele in relation to high altitude adaptation. Ann Hum Genet 65: 531-536.

39. Ward R (1995) Familial aggregation and genetic epidemiology of blood pressure; in hypertension: pathology, diagnosis, and management (eds) $\mathrm{J} \mathrm{H}$ Laragh and B M Brenner (New York: Raven Press): 67-88.

40. Qi Y, Sun J, Zhu T, Wang W, Liu J, et al. (2011) Association of angiotensinconverting enzyme gene insertion/deletion polymorphism with high-altitude pulmonary oedema: a meta-analysis. J Renin Angiotensin Aldosterone Syst 12 : 617-623.

41. Bhagi S, Srivastava S2, Tomar A3, Bala Singh S, Sarkar S1 (2015) Positive Association of D Allele of ACE Gene With High Altitude Pulmonary Edema in Indian Population. Wilderness Environ Med 26: 124-132.

42. Ahluwalia TS, Ahuja M, Rai TS, Kohli HS, Bhansali A, et al. (2009) ACE variants interact with the RAS pathway to confer risk and protection against type 2 diabetic nephropathy. DNA Cell Biol 28: 141-150.

43. Tipnis SR, Hooper NM, Hyde R, Karran E, Christie G, et al. (2000) A human homolog of angiotensin-converting enzyme. Cloning and functional expression as a captopril-insensitive carboxypeptidase. J Biol Chem 275: 33238-33243.

44. Donoghue M, Hsieh F, Baronas E, Godbout K, Gosselin M, et al. (2000) A nove angiotensin-converting enzyme-related carboxypeptidase (ACE2) converts angiotensin I to angiotensin 1-9. Circ Res 87: E1-9.

45. Santos RA, Ferreira AJ, Simões E Silva AC (2008) Recent advances in the angiotensin-converting enzyme 2-angiotensin(1-7)-Mas axis. Exp Physiol 93 $519-527$

46. Huang W, Yang W, Wang Y, Zhao Q, Gu D, et al. (2006) Association study of angiotensin-converting enzyme 2 gene (ACE2) polymorphisms and essentia hypertension in northern Han Chinese. J Hum Hypertens 20: 968-971.

47. Benjafield AV, Wang WY, Morris BJ (2004) No association of angiotensinconverting enzyme 2 gene (ACE2) polymorphisms with essential hypertension. Am J Hypertens 17: 624-628.

48. Zhong J, Yan Z, Liu D, Ni Y, Zhao Z, et al. (2006) Association of angiotensinconverting enzyme 2 gene $A / G$ polymorphism and elevated blood pressure in Chinese patients with metabolic syndrome. J Lab Clin Med 147: 91-95.

49. Patel SK, Wai B, Ord M, Maclsaac RJ, Grant S, et al. (2012) Association of ACE2 genetic variants with blood pressure, left ventricular mass, and cardiac function in Caucasians with type 2 diabetes. Am J Hypertens 25: 216-222.

50. de Gasparo M, Husain A, Alexander W, Catt KJ, Chiu AT, et al. (1995) Proposed update of angiotensin receptor nomenclature. Hypertension 25: 924-927.

51. Timmermans PB, Benfield P, Chiu AT, Herblin WF, Wong PC, et al. (1992) Angiotensin II receptors and functional correlates. Am J Hypertens 5 221S-235S.

52. Timmermans PB, Wong PC, Chiu AT, Herblin WF, Benfield P, et al. (1993) Angiotensin II receptors and angiotensin II receptor antagonists. Pharmacol Rev 45: 205-251.
53. Horiuchi M (1996) Functional aspects of angiotensin type 2 receptor. Adv Exp Med Biol 396: 217-224.

54. Csikós T, Chung O, Unger T (1998) Receptors and their classification: focus on angiotensin II and the AT2 receptor. J Hum Hypertens 12: 311-318.

55. Chiu AT, McCall DE, Nguyen TT, Carini DJ, Duncia JV, et al. (1989) Discrimination of angiotensin II receptor subtypes by dithiothreitol. Eur J Pharmacol 170: 117-118.

56. Murphy TJ, Alexander RW, Griendling KK, Runge MS, Bernstein KE (1991) Isolation of a cDNA encoding the vascular type-1 angiotensin II receptor. Nature 351: 233-236.

57. Sasaki K, Yamano Y, Bardhan S, Iwai N, Murray JJ, et al. (1991) Cloning and expression of a complementary DNA encoding a bovine adrenal angiotensin II type-1 receptor. Nature 351: 230-233.

58. Griendling KK, Alexander RW (1993) The angiotensin (AT1) receptor. Semin Nephrol 13: 558-566.

59. Hunyady L, Balla T, Catt KJ (1996) The ligand binding site of the angiotensin AT1 receptor. Trends Pharmacol Sci 17: 135-140.

60. Takayanagi R, Ohnaka K, Sakai Y, Nakao R, Yanase T, et al. (1992) Molecular cloning, sequence analysis and expression of a cDNA encoding human typeangiotensin II receptor. Biochem Biophys Res Commun 183: 910-916.

61. Wang WY, Zee RY, Morris BJ (1997) Association of angiotensin II type 1 receptor gene polymorphism with essential hypertension. Clin Genet 51: 31-34

62. Szombathy T, Szalai C, Katalin B, Palicz T, Romics L, et al. (1998) Association of angiotensin II type 1 receptor polymorphism with resistant essential hypertension. Clin Chim Acta 269: 91-100.

63. Castellano M, Muiesan ML, Beschi M, Rizzoni D, Cinelli A, et al. (1996) Angiotensin II type 1 receptor A/C1166 polymorphism. Relationships with blood pressure and cardiovascular structure. Hypertension 28: 1076-1080.

64. Kiely DG, Cargill RI, Wheeldon NM, Coutie WJ, Lipworth BJ (1997) Haemodynamic and endocrine effects of type 1 angiotensin II receptor blockade in patients with hypoxaemic cor pulmonale. Cardiovasc Res 33: 201-208.

65. O'Keefe JH, Wetzel M, Moe RR, Bronsnahan K, Lavie CJ (2001) Should an angiotensin-converting enzyme inhibitor be standard therapy for patients with atherosclerotic disease? J Am Coll Cardiol 37: 1-8.

66. Basile J, Toth PP (2009) Angiotensin receptor blockers: role in hypertension management, cardiovascular risk reduction, and nephropathy. South Med 102: S1-1S12.

67. Kaibara M, Mitarai S, Yano K, Kameyama M (1994) Involvement of $\mathrm{Na}(+)-\mathrm{H}+$ antiporter in regulation of L-type $\mathrm{Ca} 2+$ channel current by angiotensin II in rabbit ventricular myocytes. Circ Res 75: 1121-1125.

68. Quignard JF, Mironneau J, Carricaburu V, Fournier B, Babich A, et al. (2001) Phosphoinositide 3-kinase gamma mediates angiotensin Il-induced stimulation of L-type calcium channels in vascular myocytes. J Biol Chem 276: 3254532551.

69. Bénitah JP, Vassort G (1999) Aldosterone upregulates $\mathrm{Ca}(2+)$ current in adult rat cardiomyocytes. Circ Res 85: 1139-1145.

70. Srivastava S, Bhagi S, Kumari B, Chandra K, Sarkar S, et al. (2012) Association of polymorphisms in angiotensin and aldosterone synthase genes of the reninangiotensin-aldosterone system with high-altitude pulmonary edema. J Renin Angiotensin Aldosterone Syst 13: 155-160. 